\title{
Butterflies and moths (Lepidoptera) in urban habitats: the moths of Warsaw. III. Noctuoidea (second part): Notodontidae, Arctiidae, Lymantriidae
}

\author{
Grażyna WINIARSKA
}

Museum and Institute of Zoology PAS, Wilcza 64,00-679 Warszawa, Poland; e-mail:grazyna@ robal.miiz.waw.pl

\begin{abstract}
Notodontidae, Lymantriidae and Arctiidae have been recorded in Warsaw to date. These include 67 species recorded in historical times, one of which, namely, Parocneria detrita, is now regarded as extinct in Poland. Contemporary records from Warsaw are not available for 19 of them. Most of these species still occur in Poland, but are often classified as rare or even critically threatened with extinction. The biggest richness and diversity of Notodontidae, Lymantriidae and Arctiidae species can be found in urban parks and reserves.
\end{abstract}

Key words: Notodontidae, Lymantriidae, Arctiidae, Lepidoptera, urban habitats, Warsaw

\section{INTRODUCTION}

Prominents (Notodontidae), tussock moths (Lymantriidae) and tiger moths (Arctiidae) belong to Noctuoidea - the biggest and best known superfamily of Lepidoptera in Poland. 36 species of Notodontidae, 16 species of Lymantriidae and 45 species of Arctiidae have been recorded from our country to date. Most of them are associated with forests and similar habitats (e.g. parks and clumps of trees in fields). The caterpillars of Notodontidae occur in forests, parks and clumps of trees in fields and feed on deciduous trees, caterpillars of Lymantriidae occur in deciduous and coniferous forests, feeding on trees and shrubs. Some of them, e.g. Lymantria monacha, cause considerable damage to forests when appearing in large numbers. The larvae of Arctiidae are polyphagous, feeding both on lichens, trees and shrubs and on herbaceous plants.

While Notodontidae, Lymantriidae and Arctiidae are well-researched taxa, little is known about their occurrence in urbanized habitats. No significant papers on the species composition of Notodontidae, Lymantriidae and Arctiidae in these habitats had been published until the end of the $19^{\text {th }}$ century. The earliest contributions date back to the first half of the $20^{\text {th }}$ century: a paper by Slastshevsky (1911), containing detailed data on the species composition of Macrolepidoptera in Warsaw and by then nearby towns, such as Pyry, Pomiechówek, Milanówek and Rembertów, and a paper by Patryn (1947), who conducted observations in Bielany, Grochów, Rembertów and Młociny (suburbs of Warsaw). Some data can also be found in papers by Adamczewski (1936, 1951 and 1964) and in unpublished materials collected by Adamczewski and Winiarska in the centre of Warsaw between 1961 and 2002. One of more recent works, by Sielezniew \& Stankiewicz (2002), presents the list of the Macrolepidoptera Heterocera in the "Las Natoliński" reserve, one of the most biologically valuable areas in Warsaw.

The present paper is based on data from literature, collections of the Museum and Institute of Zoology, PAS and previously unpublished materials collected by Adamczewski in the years 1963-1980 and by Winiarska in the years 1976-1978 and 1998-2002 in the centre of Warsaw (see Winiarska 2003a). The present paper contains a list of species recorded in Warsaw from 
historical times until 2002 together with brief descriptions. It is the third of a series of papers which aims to present the species composition of Lepidoptera occurring in urban habitats. Together, these publications will form a basis for a comprehensive monograph presenting the process of settlement of urban habitats by Lepidoptera and changes that occur in communities of this insects under the influence of increasing anthropogenic pressure as the city develops.

The names and systematic arrangement of taxa at family level in Table 1 are based on the inventory of European Lepidoptera (Karlsholt \& Razowski 1996) with some modifications based on the inventory of Danish Lepidoptera (Karlsholt \& Nielsen 1998), after Buszko \& Nowacki 2000. Two periods are distinguished (as in Buszko \& Nowacki 2000): early $19^{\text {th }}$ century - 1960 (historical records) and since 1960 (contemporary records). Data on the abundance of individual species, their biology and distribution in Europe have been excerpted from Buszko (1997).

\section{SPECIES COMPOSITION}

As many as 68 species of the families: Notodontidae (27 species), Lymantriidae (10 species) and Arctiidae (31 species) have been recorded in Warsaw to date, representing about $70 \%$ of the total number of this families species ever reported from Poland (Table 1).

\section{HISTORICAL RECORDS}

67 species of Notodontidae (26 species), Lymantriidae (10 species) and Arctiidae (31 species) were registered in Warsaw during the historical period (Table 1). As many as $71 \%$ of these species can still be found in Warsaw.

Table 1. Checklist of Notodontidae, Lymantriidae and Arctiidae in Warsaw and Mazovia; WA - whole area of Poland, AWA - almost whole area of Poland, PP - part of Poland, R - rare, EX - extinct in Poland*, CR - critically endangered*, EN - endangered*, VU - vulnerable*, NT - near threatened, * by "Polish Red List" - Buszko \& Nowacki (2002).

\begin{tabular}{|c|c|c|c|c|c|c|}
\hline \multirow[b]{2}{*}{ No. } & \multirow[b]{2}{*}{ Species } & \multicolumn{2}{|c|}{ Warsaw } & \multicolumn{2}{|c|}{ Poland } & \multirow[b]{2}{*}{ Notes } \\
\hline & & Up to 1960 & \begin{tabular}{|c|} 
From 1961 \\
to 2001 \\
\end{tabular} & Mazovia & Poland & \\
\hline 1 & 2 & 3 & 4 & 5 & 6 & 7 \\
\hline & Notodontidae & & & & & \\
\hline & Pygaerinae & & & & & \\
\hline 1 & Clostera curtula (L.) & + & + & + & WA & \\
\hline 2 & Clostera anachoreta (Den. et Schiff.) & + & + & + & WA, R & \\
\hline 3 & Clostera anastomosis (L.) & + & + & + & WA & \\
\hline 4 & Clostera pigra (Hufn.) & + & + & + & WA & \\
\hline & Notodontinae & & & & & \\
\hline 5 & Cerura vinula (L.) & + & + & + & WA & \\
\hline 6 & Cerura erminea (Esp.) & + & + & + & WA & \\
\hline 7 & Furcula furcula $(\mathrm{Cl})$. & + & + & + & WA & \\
\hline 8 & Furcula bicuspis (Bkh.) & + & & + & AWA & \\
\hline 9 & Furcula bifida (Brahm) & + & + & + & WA & \\
\hline 10 & Notodonta dromedarius (L.) & + & + & + & WA & \\
\hline 11 & Notodonta torva (Hbn.) & & + & + & AWA & \\
\hline 12 & Notodonta tritophus (Den. et Schiff.) & + & + & + & WA, R & \\
\hline 13 & Notodonta ziczac (L.) & + & + & + & WA & \\
\hline 14 & Drymonia dodonaea (Den. et Schiff.) & + & + & + & WA & \\
\hline 15 & Drymonia ruficornis (Hufn.) & + & + & + & WA & \\
\hline 16 & Drymonia velitaris (Hufn.) & + & & + & $\mathrm{PP}, \mathrm{R}$ & NT \\
\hline 17 & Pheosia tremula $(\mathrm{Cl})$. & + & + & + & WA & \\
\hline 18 & Pheosia gnoma (F.) & + & + & + & WA & \\
\hline 19 & Pterostoma palpina $(\mathrm{Cl})$. & + & + & + & WA & \\
\hline
\end{tabular}




\begin{tabular}{|c|c|c|c|c|c|c|}
\hline 1 & 2 & 3 & 4 & 5 & 6 & 7 \\
\hline 20 & Leucodonta bicoloria (Den. et Schiff.) & + & + & + & WA & \\
\hline 21 & Ptilodon capucina $(\mathrm{L})$. & + & + & + & WA & \\
\hline 22 & Gluphisia crenata (Esp.) & + & + & + & WA & \\
\hline & Phalerinae & & & & WA & \\
\hline 23 & Phalera bucephala (L.) & + & + & + & WA & \\
\hline 24 & Peridea anceps (Goeze) & + & + & + & AWA & \\
\hline & Heterocampinae & & & & & \\
\hline 25 & Stauropus fagi (L.) & + & + & + & WA & \\
\hline 26 & Harpyia milhauseri (F.) & + & + & + & WA, R & \\
\hline 27 & Spatalia argentina (Den. et Schiff) & + & & + & $\mathrm{PP}, \mathrm{R}$ & VU \\
\hline & Lymantriidae & & & & & \\
\hline 28 & Lymantria monacha (L.) & + & + & + & WA & \\
\hline 29 & Lymantria dispar (L.) & + & + & + & WA & \\
\hline 30 & Parocneria detrita (Esp.) & + & & + & $\mathrm{PP}, \mathrm{R}$ & EX \\
\hline 31 & Calliteara pudibunda (L.) & + & + & + & WA & \\
\hline 32 & Dicallomera fascelina $(\mathrm{L})$. & + & & + & $\mathrm{PP}, \mathrm{R}$ & \\
\hline 33 & Orgyia recens (Hbn.) & + & & + & $\mathrm{PP}, \mathrm{R}$ & \\
\hline 34 & Orgyia antiqua (L.) & + & + & + & WA & \\
\hline 35 & Euproctis chrysorrhoea (L.) & + & + & + & WA & \\
\hline 36 & Euproctis similis (Fuessly) & + & + & + & WA & \\
\hline 37 & Leucoma salicis (L.) & + & + & + & WA & \\
\hline & Arctiidae & & & & & \\
\hline & Lithosinae & & & & & \\
\hline 38 & Thumatha senex (Hbn.) & + & & + & WA & \\
\hline 39 & Miltochrista miniata (Forst.) & + & + & + & WA & \\
\hline 40 & Cybosia mesomella (L.) & + & & + & AWA & \\
\hline 41 & Pelosia muscerda (Hufn.) & + & & + & AWA & \\
\hline 42 & Atolmis rubricollis (L.) & + & + & + & WA & \\
\hline 43 & Lithosia quadra (L.) & + & + & + & WA & \\
\hline 44 & Eilema depressa (Esp.) & + & + & + & WA & \\
\hline 45 & Eilema griseola (Hbn.) & + & + & + & WA & \\
\hline 46 & Eilema lurideola (Zinck.) & + & + & + & WA & \\
\hline 47 & Eilema complana (L.) & + & + & + & WA & \\
\hline 48 & Eilema lutarella (L.) & + & + & + & WA & \\
\hline 49 & Eilema sororcula (Hufn.) & + & + & + & WA & \\
\hline 50 & Setina irrorella $(L)$. & + & + & + & AWA, R & \\
\hline & Syntominae & & & & & \\
\hline 51 & Amatha phegea (L.) & + & & + & AWA & \\
\hline 52 & Dysauxes ancilla $(\mathrm{L})$. & + & & + & AWA, R & $\mathrm{EN}$ \\
\hline & Arctiinae & & & & & \\
\hline 53 & Spiris striata (L.) & + & & + & WA & \\
\hline 54 & Coscinia cribraria (L.) & + & + & + & WA & \\
\hline 55 & Phragmatobia fuliginosa (L.) & + & + & + & WA & \\
\hline 56 & Parasemia plantaginis (L.) & + & & + & AWA & \\
\hline 57 & Spilosoma lutea (Hufn.) & + & + & + & WA & \\
\hline 58 & Spilosoma lubricipeda (L.) & + & + & + & WA & \\
\hline 59 & Spilosoma urticae (Esp.) & + & + & + & WA & \\
\hline 60 & Diaphora mendica $(\mathrm{Cl})$. & + & & + & AWA & \\
\hline 61 & Rhyparia purpurata (L.) & + & & + & AWA & \\
\hline 62 & Diacrisia sannio (L.) & + & & + & WA & \\
\hline 63 & Hyphoraia aulica (L.) & + & & + & AWA & $\mathrm{EN}$ \\
\hline 64 & Arctia caja (L.) & + & + & + & WA & \\
\hline 65 & Arctia villica (L.) & + & + & + & $\mathrm{PP}, \mathrm{R}$ & VU \\
\hline 66 & Arctia festiva (Hufn.) & + & & & $\mathrm{PP}, \mathrm{R}$ & $\mathrm{CR}$ \\
\hline 67 & Callimorpha dominula (L.) & + & + & + & WA & \\
\hline 68 & Tyria jacobaeae (L.) & + & & + & WA & \\
\hline
\end{tabular}


Only the following 3 species of Notodontidae: Furcula bicuspis, Drymonia velitaris i Spatalia argentina have not been reported since 1960. F. bicuspis is a rather rare species found locally all over Poland in moist deciduous and mixed forests, parks and shrubs. D. velitaris belong to a group of species associated with Potentillo albae-Quercetum oak forests and thermophilous shrubs that also contains the rarest Notodontidae. This species has only been recorded from a few localities in southern and central Poland and is not threatened with extinction, being classified as near threatened (NT) in the Polish Red List (Buszko \& Nowacki 2002). S. argentina (classified as vulnerable (VU) in the Polish Red List) is a rare species recorded from scattered localities all over Poland representing similar habitats to those supporting Drymonia velitaris. These species were reported by Slastshevsky from the then environs of Warsaw (Slastshevsky 1911).

Three species of Lymantriidae: Parocneria detrita, Dicallomera fascelina and Orgyia recens occurred in Warsaw only in historical times. One of them, $P$. detrita, is now regarded as extinct in Poland. This species is associated with Potentillo albae-Quercetum oak forests. It was found by Patryn (1947) in a suburb of Warsaw in 1935. The other two species can still be found all over Poland, being, however, rare and local. D. fascelina is associated with heathergrown areas, well-insolated slopes and felling sites, where the caterpillars feed on Sarothamnus scoparius, Calluna vulgaris and Rubus. O. recens inhabits deciduous and mixed forests, parks and orchards, the larvae feeding on the leaves of trees and deciduous shrubs, primarily of the family Rosaceae. Both species were recorded by Slastshevsky (1911) from the then environs of Warsaw.

As many as 13 species of the family Arctiidae were only found in historical times. Four of them are on the Polish Red List, namely Arctia festiva (CR - critically endangered), Dysauxes ancilla, Hyphoraia aulica (EN - endangered) and Arctia villica (VU - vulnerable). A. festiva used to be widespread all across the Polish lowlands, but it has not been captured there for 20 years. Patryn (1947) found it in Warsaw in 1934, but regarded it as "very rare". This species is associated with xerothermal grasslands and heather-grown areas, and its larvae feed on various herbaceous plants, including Thymus and Taraxacum. D. ancilla is a rare species found in thermophilous deciduous forests and xerothermal shrubs in the Polish lowlands and submontane areas. Its caterpillars feed on mosses and lichens. $H$. aulica is a rare species associated with xerothermal grasslands and heather-grown areas in southern Poland whose caterpillars feed on herbaceous plants. A. villica is a rare species despite its wide distribution in Poland.It is associated with warm and open-canopy deciduous forests, parks and gardens. Its caterpillars feed on herbaceous plants, such as Lamium and Achillea, and on Rubus idaeus.

\section{CONTEMPORARY RECORDS}

Contemporary reports from Warsaw list 49 species of Notodontidae (24 species), Lymantriidae ( 7 species) and Arctiidae (18 species), which represents approximately $60 \%$ of the species of this lepidopteran group occurring in Poland (Tab. 1.). The majority of the 'Warsaw' species are also common and abundant all over the country, for example Drymonia ruficornis (Notodontidae), Euproctis chrysorrhoea (Lymantriidae) and Miltochrista miniata (Arctiidae). Species that are rare or only sporadically found in Poland form a small group in the city's lepidopteran fauna. These include, among others, Setina irrorella (Arctiidae), a species widely distributed (though rare) in the Polish lowlands and associated with xerothermal slopes and dry clearings in forests (the caterpillars feed on lichens). It has been found in the contemporary period in the centre of Warsaw by Adamczewski, in 1966. Other examples include Clostera anachoreta of the family Notodontidae, which is associated with deciduous and mixed forests and has been reported from all over Poland but is not frequently caught, or 
Notodonta tritophus (Notodontidae), single specimens of which were collected by Adamczewski in the centre of Warsaw in 1961, 1962, 1977 and 1984, but which has also been reported by Sielezniew \& Stankiewicz (2002) from the "Las Natoliński" reserve. The latter species is associated with deciduous and mixed forests and reported from all over Poland except the mountains, but also rarely caught.

\section{SUMMARY}

The city is home to most species of the families Notodontidae, Lymantriidae and Arctiidae reported from Poland, with as many as $70 \%$ of such species having been found in this habitat. Here, the species are largely associated with forested areas, such as old and large parks, where their larvae can find suitable conditions for life and development. This is attested to by historical as well as contemporary data (Slastshevsky 1911, Patryn 1947, Sielezniew \& Stankiewicz 2002).

Despite changes that have taken place in the Warsaw agglomeration since World War II (including, above all, the expansion of densely built-up areas, a higher share of man-made and cultivated green areas and a reduction in the size of the area occupied by the remnants of natural Mazovian forests), there are still a relatively large number of species belonging to the three families, as demonstrated by Sielezniew \& Stankiewicz (2002) for the "Las Natoliński" urban reserve and by many years of studies in the centre of Warsaw by Adamczewski and Winiarska (unpublished data). The number of Notodontidae, Lymantriidae and Arctiidae species found in the Warsaw agglomeration in contemporary times has decreased by $30 \%$, this reduction being mostly due to the disappearance of species rarely registered in Poland, including some threatened with extinction, such as Arctia festiva and Dysauxes ancilla. The centre of the city supports many fewer species than can be found in the areas representing the remnants of natural Mazovian forests. This difference is particularly visible in the case of lepidopterans associated with deciduous forests, such as Notodontidae, with 21 species recorded over 2 years in the "Natolin Wood" reserve, compared to only 15 found in the centre of Warsaw in no less than 25 years of study! Similar trends (a reduction of about $30 \%$ in the number of species in contemporary times and the preservation of the highest species richness in areas with natural or seminatural flora, such as large parks) have also been confirmed for other butterflies and moths in the Warsaw agglomeration, for example, Noctuidae, Pantheidae and Nolidae (Winiarska 2002) and Rhopalocera (Winiarska 2003b).

\section{REFERENCES}

ADAMCZEWSKI S. 1936. Pojawy motyli w okolicach Warszawy w roku 1934. Fragm. faun. Mus. Zool. Pol., 2: $305-313$.

ADAMCZEWSKI S. 1951. Łuskoskrzydłe śródmieścia Warszawy (Lepidoptera). Fragm. faun. Mus. Zool. Pol., 6: 111-128.

ADAMCZEWSKI S. 1964. Materiały do poznania wędrówek motyli w Polsce. II. Jesienne pojawy i migracje motyli w Warszawie i Białowieży w latach 1961 i 1962. Fragm. Faun., 11: 319-374.

Buszko J. 1997. Atlas motyli Polski. Część II. Prządki, zawisaki, niedźwiedziówki. Warszawa. pp. 269.

Buszko J. \& NowACKI J. (eds) 2000. The Lepidoptera of Poland. A distributional checklist. Polish Entomological Monographs. 1. Polskie Towarzystwo Entomologiczne, Pozná-Toruń, 262 pp.

BuSzKo J. \& NOWACKI J. 2002. Motyle. In: GŁOWACIŃSKI Z. (ed.), Czerwona lista zwierząt ginących i zagrożonych w Polsce, pp. 80-92, Zakład Ochrony Przyrody PAN, Kraków, 156 pp.

KARShOlT O. \& NiELSEN P. S. 1998. Revised catalogue of the Lepidoptera of Denmark. Kobenhavn, 144 pp.

KARShOlT O. \& RAZOWSKI J. 1996. The Lepidoptera of Europe. A distributional checklist. Apollo Books, Stenstrup, $380 \mathrm{pp}$.

PATRYN W. 1947. Spis motyli dziennych (Rhopalocera) i nocnych (Noctuidae) zebranych w okolicach Warszawy. Pol. Akad. Umiejęt. Materiały do fizjografii kraju. 5: 1-50.

SielezNiEW M. \& STANKIEwICZ A. 2002. Motyle tzw. większe nocne (Macrolepidoptera, Heterocera) rezerwatu "Las Natoliński” w Warszawie. Parki nar. Rez. przyr. 21 (2): 195-205.

SLASTSHEVSKY P. 1911. Macrolepidopterofauna der Warschauer Gouvernements. Hor. Soc. Ent. Rossicae, 40: 1-132. 
WINIARSKA G. 2002. Butterflies and moths (Lepidoptera) in urban habitats: the moths of Warsaw I. Noctuidae, Pantheidae, Nolidae. Fragm. Faun. 45: 131-145.

WINIARSKA G. 2003a. Long-term changes in communities of Noctuidae, Pantheidae And Nolidae (Lepidoptera) of Warsaw city centre. Fragm. Faun. 46: 69-91.

WINIARSKA G. 2003b. Butterflies and moths (Lepidoptera) in urban habitats: II. The butterflies (Rhopalocera) of Warsaw. Fragm. Faun. 46: 59-67.

\section{STRESZCZENIE}

[Motyle (Lepidoptera) w środowisku miejskim, na przykładzie Warszawy. III. Noctuoidea (część 2): Notodontidae, Arctiidae, Lymantriidae]

Niniejsze opracowanie powstało na podstawie danych $\mathrm{z}$ piśmiennictwa, danych pochodzących ze zbiorów Muzeum i Instytutu Zoologii PAN oraz dotychczas niepublikowanych danych z materiałów Adamczewskiego (z lat 1963-1980) i Winiarskiej (z lat 1986-2001). Zawiera ono wykaz i krótką charakterystykę gatunków stwierdzonych na terenie tego miasta od czasów historycznych do 2001 roku i jest trzecią częścią opracowywanego obecnie cyklu publikacji prezentujących skład gatunkowy zgrupowań z poszczególnych rodzin motyli występujących w środowiskach zurbanizowanych.

W Warszawie stwierdzono dotychczas 68 gatunków Notodontidae, Lymantriidae i Arctiidae, co stanowi około $70 \%$ wszystkich gatunków z tych rodzin występujących w Polsce. Tylko 3 gatunki Notodontidae: Furcula bicuspis, Drymonia velitaris, Spatalia argentina, 3 gatunki Lymantriidae: Parocneria detrita, Dicallomera fascelina i Orgyia recens i aż 13 gatunków Arctiidae (wśród nich 4 znajdujące się na „Polskiej Czerwonej Liście”: Arctia festiva, Arctia villica, Dysauxes ancilla i Hyphoraia aulica) występowało tylko w czasach historycznych.

Po roku 1960 w Warszawie stwierdzono obecność 49 gatunków Notodontidae (24 gatunki), Lymantriidae (7 gatunków) i Arctiidae (18 gatunków), co stanowi ok. 60\% gatunków tych motyli występujących na terenie Polski. Na grupę tę składają się przede wszystkim gatunki pospolite w naszym kraju i wszędzie zaliczane do licznych, jak: Drymonia ruficornis (Notodontidae), Euproctis chrysorrhoea (Lymantriidae) i Miltochrista miniata (Arctiidae). Gatunki rzadkie, jak Setina irrorella (Arctiidae), stanowią niewielką część współczesnej lepidopterofauny miasta.

W środowisku miejskim motyle te są związane przede wszystkim $\mathrm{z}$ terenami zadrzewionymi, np. starymi i dużymi parkami, gdzie ich larwy znajdują odpowiednie warunki do życia i rozwoju. 